\title{
THE QUALITATIVE EVALUATION OF ANTIBIOTICS USED IN PEDIATRIC RESPIRATORY TRACT INFECTION TREATMENTS AT A PRIMARY HOSPITAL IN SURABAYA
}

\section{EVALUASI KUALITATIF ANTIBIOTIK PADA PASIEN INFEKSI SALURAN PERNAPASAN ANAK DI RUMAH SAKIT DI SURABAYA}

\author{
Ilil Maidatuz Zulfa \\ Department of Clinical, and Community Pharmacy and Pharmacy Management, \\ The Pharmacy Academy of Surabaya, Jl. Ketintang Madya No. 81, Surabaya, Indonesia \\ Email: Ilil.maidatuz@akfarsurabaya.ac.id (Ilil Maidatuz Zulfa)
}

\begin{abstract}
Respiratory Tract Infections (RTIs) commonly occur as an infection in children. A considerable amount of antibiotics consumption is used to treat RTIs in many hospitals. Unwise antibiotic treatments in RTIs will increase bacterial resistance and treatment cost. This study aimed to investigate the quality or appropriateness of antibiotics use in RTI treatments in pediatric inpatients. A retrospective analysis of antibiotics consumption data was conducted through inpatient medical records for three months in 2017 at a primary hospital in Surabaya, Indonesia. The qualitative assessment was performed using a modified Gyssens algorithm based on the National Guideline and other relevant international standards of antibiotics applications in RTI treatment. The medical records of a total of 87 pediatric inpatients aged 0-14 y.o. were included in this study. The most common diagnosis was tonsillopharyngitis (32.18\%), and the average length of hospital stay was 4.84 days. Antibiotics used in the treatments were from the class of $\beta$-lactams and cephalosporins, all of which were applied in empirical therapy. According to the analysis, the antibiotic treatments were not appropriate. The most inappropriate use of antibiotics was in the form of wrong choice of drug choice (95.40\%), followed by the sub-optimal duration of antibiotics (4.60\%). The RTI treatment in pediatrics has to avoid any inappropriate uses of antibiotics, which can be achieved through the evaluation of institutional policy against the local guideline, antibiogram, or any relevant international guidelines.
\end{abstract}

Key words: appropriate use of antibiotics, Gyssens methods, Respiratory Tract Infection (RTI). 


\section{Introduction}

Respiratory Tract Infections

(RTIs) are acute infections involving upper or lower respiratory tract or even both, which commonly occur in children and adults (The Indonesian Ministry of Health, 2005). The upper respiratory tract includes the nose, paranasal sinuses, pharynx, larynx, and upper trachea, while the lower respiratory tract includes bronchus and alveolus (The Indonesian Ministry of Health, 2005; Mamo and Teshome, 2017). A survey by the Indonesian Ministry of Health reported that the prevalence of RTIs in 2013 was $25 \%$, and children aged 1-4 y.o. were the most represented RTIcontracted group (25.8\%) (The Indonesian Ministry of Health, 2013).

RTIs are usually caused by a viral infection. However, bacterial pathogens are also identified as the cause of RTIs (Arroll and Kenealy, 2005; Karevold et al., 2006). Secondary infection by bacteria in viral RTIs is not preventable, yet some clinicians prescribe antibiotics to prevent secondary bacterial infection. Consequently, a considerable amount of antibiotics is consumed to treat inpatients with RTIs (Gonzales et al., 1997; Reese et al., 2000). Unwise or inappropriate antibiotic treatments of RTIs will increase bacterial resistance, treatment cost, and adverse drug reactions (Alumran et al., 2011). Therefore, this study aimed to investigate the quality or the appropriateness of antibiotics use in RTI treatments in pediatric inpatients at a primary care hospital in Surabaya, Indonesia.

\section{Methods}

The study was conducted at a primary care hospital in Surabaya City from January to March 2018. The name of the hospital could not be mentioned because of ethical reason. A crosssectional study was conducted using retrospective data. The source of the data was medical and prescription records of all of the pediatric inpatients diagnosed with RTIs who were hospitalized during October-December 2017. All patient's information acquired from medical records was used only for the research purpose. Personal information was not used in the research by any means. Patients who had other comorbidities of infectious diseases for which antibiotics could be administered were excluded. 


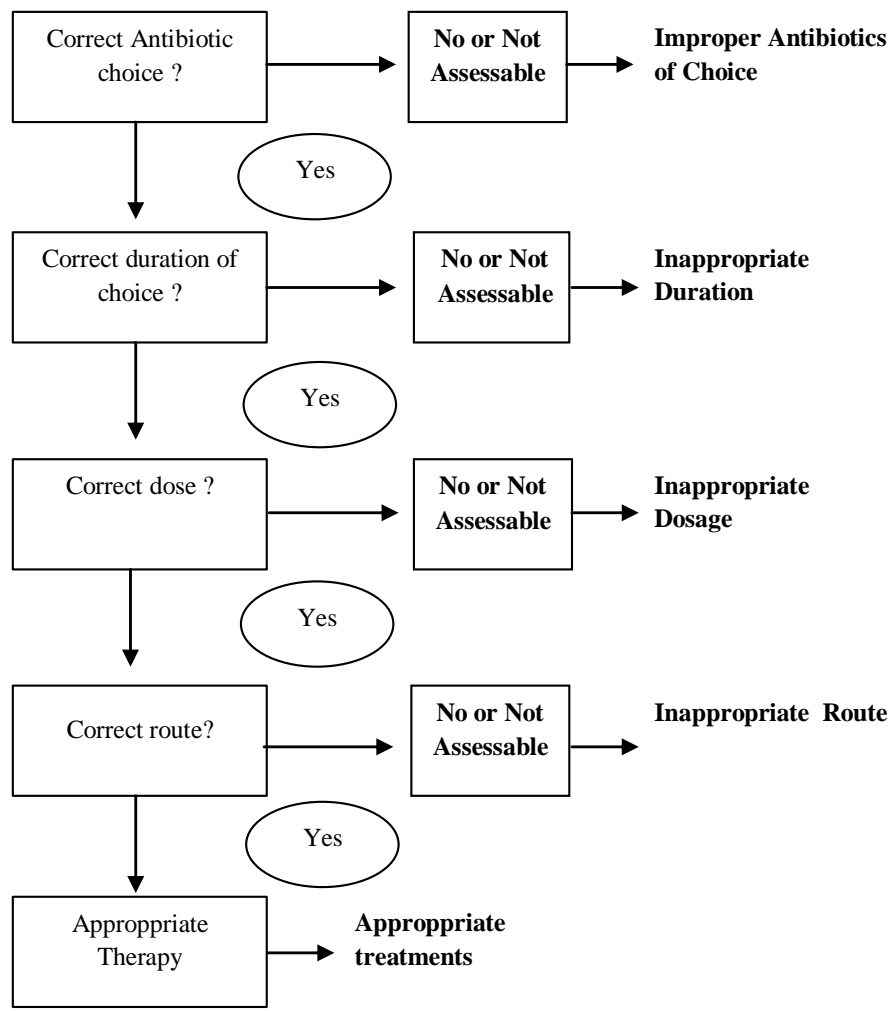

Figure 1. The modified Gyssens algorithm.

The data was collected using a checklist that suited the research purpose. The descriptive analysis was conducted in Microsoft Excel ${ }^{\mathrm{TM}}$ 2007, while the qualitative investigation of the appropriateness of antibiotics usage was carried out using the modified Gyssens algorithm adapted from Baktygul et al. (2011) and based on the national guideline issued by the Indonesian Ministry of Health and other international standards for RTI treatments in children. The international standards used were the guideline for the management of acute bronchitis and acute pharyngitis developed by the Alberta Medical Association (2008a, 2008b) in Canada and the Guideline for the Management of Community-Acquired Pneumonia published by Oxford University Press on behalf of the Infectious Diseases Society of America. The assessment using the modified Gyssens algorithm started from the examination of the antibiotics choice due to the use of retrospective data, which assumed that all of the diagnoses were a bacterial infection 
(Figure 1). Treatments were considered appropriate when the indication, choice of agent, duration, and dose corresponded to the guidelines.

\section{Results}

Patients' Demographic and Clinical Characteristics

A total of 87 patient medical records from children diagnosed with RTIs during October-December 2017 were investigated in this study. The male to female patient ratio was 1.23 (the distribution is presented in Table 1). Most of the patients were in the age group of $0-4$ y.o. (67.82\%), followed by the age group of 5-9 y.o. (27.59\%). There were several types of RTI cases observed. The three main types were bronchitis (5.75\%), pneumonia (14.94\%), and pharyngitis (79.31\%). Each of them was further classified into many subtypes, and the most common subtype was tonsillopharyngitis (32.18\%) (Figure 2). The average number of antibiotics prescription per patient was between $1-2(21.84 \%$ of patients received a combination of two antibiotics), and the average length of hospital stay was 4.84 days.

Table 1. Patients' demographic and clinical characteristics

\begin{tabular}{lcc}
\hline Characterictics & $\begin{array}{c}\text { Number of } \\
\text { Patients }\end{array}$ & Percentages (\%) \\
\hline Gender & 39 & \\
$\quad$ Female & 48 & 44.83 \\
$\quad$ Male $\quad$ Total & 87 & 55.17 \\
Age (years) & & 100.00 \\
$0-4$ & 59 & \\
$5-9$ & 24 & 67.82 \\
10-14 & 4 & 27.59 \\
Total & 50 & 4.60 \\
Length of hospital stay (days) & Mean \pm SD & $4.84 \pm 1.06$ \\
Antibiotics prescription per patient & Mean \pm SD & $1.17 \pm 0.38$ \\
Combination therapy with two antibiotics & 19 & 21.84 \\
\hline
\end{tabular}

Different classes and doses of antibiotics were used for all of the RTI cases observed in this study. There were 109 prescriptions reviewed for 87 patients. The mean duration of therapy for all antibiotics usage was 3.88 days with a range of 3-5 days. The route of antibiotics administration were 
intravenous (67.82\%) and oral (33.28\%). The groups of antibiotics used in the treatment were $\beta$-lactams, including cephalosporins. The antibiotics prescription mostly included ampicillinsulbactam, which was prescribed in all of the RTI cases $(32.11 \%$ cases) at a dose of $46.15-75.18 \mathrm{mg} / \mathrm{kg} /$ day. The other prescribed antibiotics were ampicillin in $39.45 \%$ cases at a dose of 58.80-99.36 mg/kg/day, followed by amoxicillin in $11.01 \%$ cases at a dose of 33.33-50.00 mg/kg/day. The most prescribed cephalosporin was cefotaxime, which was used only in 9.17 $\%$ cases. Table 2 shows the antibiotics therapy profile.

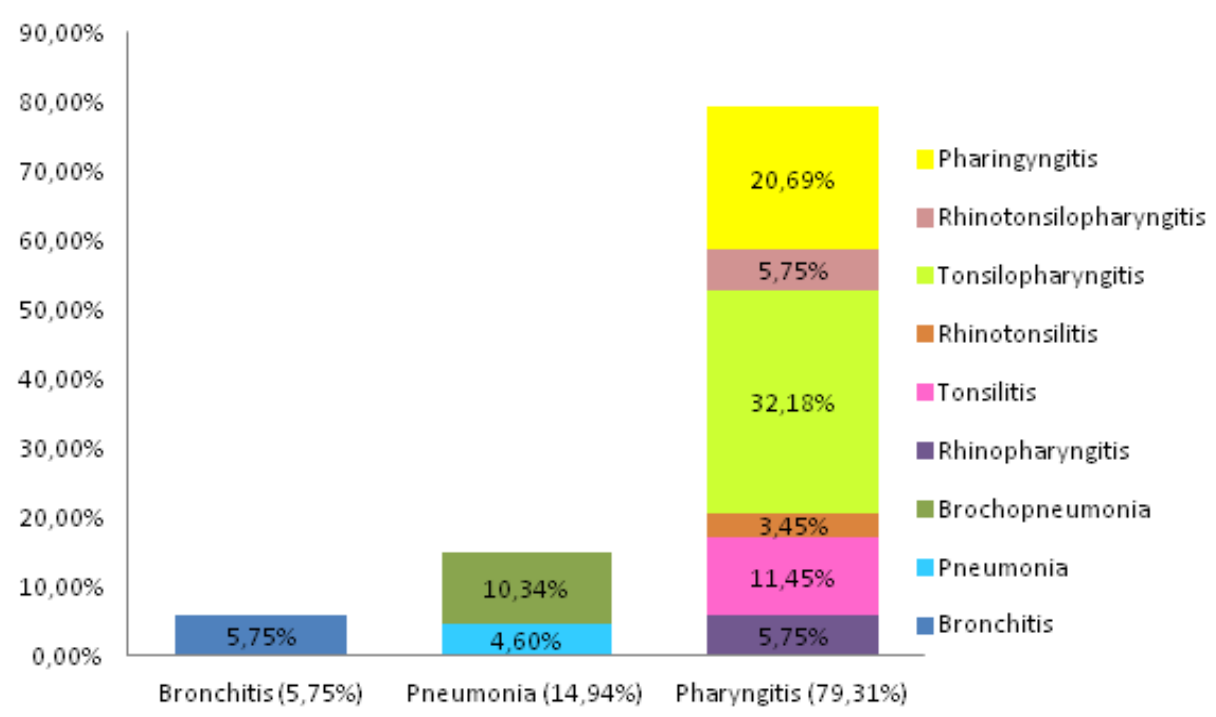

Figure 2. Types of RTIs.

\section{Antibiotic Treatment Quality}

A total of 87 patient medical records, containing 109 antibiotics prescriptions were reviewed. According to the guidelines used in this study, antibiotic treatment was found to be inappropriate in all patients (100.00\%) (Table 3).

The most common category for inappropriateness was the improper choice of antibiotics, which was found in 83 cases (Table 4$)$. The second most common category was the inappropriate duration of antibiotic therapy, which was identified in 4 cases (4.60\%). The comparison of antibiotics prescription and the national and international guidelines is provided in Table 5. 
Vol. 15 No. 02 Desember 2018

Table 2. Antibiotics therapy profile

\begin{tabular}{|c|c|c|c|c|c|c|}
\hline Antibiotics & Diagnoses & Routes & $\begin{array}{c}\text { Mean } \\
\text { Duration of } \\
\text { Use (days) }\end{array}$ & Freq. (daily' & $\begin{array}{l}\text { Mean Dosage } \\
\text { (mg/kg/day) }\end{array}$ & $\begin{array}{c}n(\%) \\
N=109\end{array}$ \\
\hline \multicolumn{7}{|l|}{ Penicillins } \\
\hline Amoxicillin & Pneumonia & Oral & 4.38 & 3 & 39.00 & $8(7.36)$ \\
\hline (J01CA04) & Pharyngitis & Oral & 4.25 & 3 & 37.37 & $4(3.70)$ \\
\hline Ampicillin & Bronchitis & IV & 4.00 & $2-3$ & 86.88 & $2(1.85)$ \\
\hline \multirow[t]{2}{*}{ (J01CA01) } & Pneumonia & IV & 4.11 & $2-4$ & 96.04 & $10(9.19)$ \\
\hline & Pharyngitis & IV & 3.58 & $2-3$ & 66.15 & $31(28.45)$ \\
\hline Ampicillin+ & Bronchitis & IV & 3.00 & 3 & 62.28 & $3(2.75)$ \\
\hline Sulbactam & Pneumonia & IV & 4.50 & 2 & 50.86 & $2(1.85)$ \\
\hline (J01CR01) & Pharyngitis & IV & 3.53 & $2-4$ & 63.32 & $30(27.53)$ \\
\hline Total Penicillins & & & & & & $90(82.57)$ \\
\hline \multicolumn{7}{|l|}{ Cephalosporins } \\
\hline $\begin{array}{l}\text { Cefadroxil } \\
\text { (J01DB05) }\end{array}$ & Pharyngitis & Oral & 5.00 & 2 & 25.00 & $1(0.92)$ \\
\hline Cefixime & Pneumonia & Oral & 4.00 & 2 & 4.62 & $1(0.92)$ \\
\hline (J01DD08) & Pharyngitis & Oral & 4.50 & 2 & 5.29 & $4(3.67)$ \\
\hline $\begin{array}{l}\text { Cefotaxime } \\
\text { (J01DD01) }\end{array}$ & Pharyngitis & IV & 3.30 & 2 & 39.37 & $10(9.19)$ \\
\hline Ceftriaxone & Pneumonia & IV & 5.00 & 2 & 55.56 & $1(0.92)$ \\
\hline (J01DD04) & Pharyngitis & IV & 3.00 & 2 & 35.00 & $2(1.85)$ \\
\hline Total Cephalosporins & & & & & & 19 (17.43) \\
\hline TOTAL & & & & & & $109(100.00)$ \\
\hline
\end{tabular}

Table 3. The Appropriateness of the antibiotic treatments

\begin{tabular}{cc}
\hline Appropriate (\%) & Inappropriate (\%) \\
\hline 0.00 & 100.00 \\
\hline
\end{tabular}

Table 4. The inappropriateness categories of the antibiotics treatments

\begin{tabular}{lccccc}
\hline & $\begin{array}{c}\text { Improper } \\
\text { Choice of } \\
\text { Antibiotics }\end{array}$ & $\begin{array}{c}\text { Inappropriate } \\
\text { Duration }\end{array}$ & $\begin{array}{c}\text { Inappropriate } \\
\text { Dosage }\end{array}$ & $\begin{array}{c}\text { Improper } \\
\text { Route }\end{array}$ & $\begin{array}{c}\text { Total } \\
\mathbf{N}(\%)\end{array}$ \\
\hline Diagnoses & & & & & \\
Bronchitis & 5 & 0 & 0 & 0 & $5(5.75)$ \\
Pneumonia & 9 & 4 & 0 & 0 & $13(14.94)$ \\
Pharyngitis & 69 & 0 & 0 & 0 & $69(79.31)$ \\
Total & $\mathbf{8 3 ( 9 5 . 4 0 )}$ & $\mathbf{4 ( 4 . 6 0 )}$ & $\mathbf{0 ( 0 . 0 0 )}$ & $\mathbf{0 ( 0 . 0 0 )}$ & $\mathbf{8 7}(\mathbf{1 0 0 . 0 0 )}$ \\
\hline
\end{tabular}


Vol. 15 No. 02 Desember 2018

Table 5. The compliance of antibiotics prescription with the guidelines

\begin{tabular}{|c|c|c|c|}
\hline \multirow{2}{*}{ Diagnosis } & \multicolumn{2}{|c|}{ Drugs to be Prescribed as per Guidelines } & \multirow{2}{*}{ Actual Drug Prescription } \\
\hline & National Guideline & International Guideline & \\
\hline Bronchitis & $\begin{array}{l}<6 \text { days: No Antibiotics } \\
\text { needed } \\
\text { First Line: } \\
\text { Amoxicillin or Quinolones } \\
\text { Alternatives: } \\
\text { Amoxicillin-clavulanate or } \\
\text { Azithromycin or } \\
\text { Cotrimoxazole }\end{array}$ & No Antibiotics & $\begin{array}{l}\text { Ampicillin, } \\
\text { Ampicillin+Sulbactam }\end{array}$ \\
\hline Pneumonia & $\begin{array}{l}\text { Erythromycin or } \\
\text { Azitromycin or } \\
\text { Claritromycin }\end{array}$ & $\begin{array}{l}\text { First Line: } \\
\text { Ampicillin or Penicillin G } \\
\text { Alternatives: } \\
\text { Ceftriaxone or } \\
\text { Cefotaxime or Levofloxac } \\
\text { in addition of } \\
\text { Vancomycin or } \\
\text { Clindamycin for } \\
\text { suspected CA-MRSA }\end{array}$ & $\begin{array}{l}\text { Ampicillin, } \\
\text { Ampicillin + Amoxicillin, } \\
\text { Ampicillin-Sulbactam, } \\
\text { Ampicillin-Sulbactam + } \\
\text { Amoxicillin } \\
\text { Ampicillin-Sulbactam + } \\
\text { Cefixime, } \\
\text { Ceftriaxone }\end{array}$ \\
\hline Pharyngitis & $\begin{array}{l}\text { First Line: } \\
\text { Amoxicillin or Amoxicillin- } \\
\text { clavulanate, Penicillin G or } \\
\text { Penicillin VK } \\
\text { Alternatives: } \\
\text { Erithromycin or } \\
\text { Azithromycin or } \\
\text { Claritromycin or } \\
\text { first/second generations } \\
\text { of Cephalosporins or } \\
\text { Levofloxacin }\end{array}$ & $\begin{array}{l}\text { First Line: } \\
\text { Penicillin VK } \\
\text { Alternatives: } \\
\text { Clindamycin or } \\
\text { Erithromycin }\end{array}$ & $\begin{array}{l}\text { Ampicillin, } \\
\text { Ampicillin + Cefadroxil, } \\
\text { Ampicillin + Cefixime, } \\
\text { Ampicillin + Cefotaxime, } \\
\text { Ampicillin-Sulbactam, } \\
\text { Ampicillin-Sulbactam + } \\
\text { Amoxicillin, } \\
\text { Cefotaxime, } \\
\text { Ceftriaxone, } \\
\text { Cefotaxime + Cefixime }\end{array}$ \\
\hline
\end{tabular}

\section{Discussion}

The inappropriate use of antibiotics is predominant in developing countries even though the guidelines for antimicrobial prescription have been established globally for many years (Blomberg, 2008; Byarugaba, 2004). Therefore, the assessment of antibiotics use patterns in the treatment of various diseases, especially in areas where antibiotics misuse commonly occurs, is crucial. Furthermore, it may indicate the groups of antibiotics that are highly misused. This study aimed to evaluate the quality or appropriateness of antibiotics usage in the treatment of RTIs in pediatric inpatients at a primary care hospital in Surabaya city, Indonesia. 
A total of two groups of antibiotics (penicillins and cephalosporins) were used at the studied hospital to treat 87 RTIs cases, which were classified into three types of RTIs (i.e., bronchitis, pneumonia, and pharyngitis). All of the antibiotic treatments were empirical therapy. The penicillin groups used in the treatment were amoxicillin, ampicillin, and the combination of ampicillin and sulbactam. Meanwhile, the group of cephalosporins used in the treatment were cefadroxil, cefixime, cefotaxime, and ceftriaxone. The penicillin groups were predominantly used, i.e., in 90 prescriptions (82.57\%).

The antibiotics used in bronchitis cases were ampicillin and the combination of ampicillin andsulbactam. Bronchitis is an inflammation of the large airway inside the lung called bronchi, which occurs as an acute or chronic inflammation (Mukherjee, 2009). The usual cause of acute bronchitis is viruses, while chronic bronchitis results from the inhalation of many respiratory tract irritants (Mukherjee, 2009; Wenzel and Fowler, 2006). Therefore, most cases of bronchitis require no more than symptomatic treatments. Antibiotic treatment for bronchitis may be considered for in patients with chronic lung disease (e.g., chronic obstructive pulmonary disease (COPD), or emphysema), or patients at high risk of pneumonia (e.g., immunocompromised) (Grigoryan et al., 2017). The international guidelines used in this study do not recommend antibiotics for bronchitis. On the other hand, the national guideline suggests some antibiotics for bronchitis, namely amoxicillin or quinolones as first choice and amoxicillin-clavulanate, azithromycin, or cotrimoxazole as the recommended alternatives. Hence, the five (5) bronchitis cases in this study were considered receiving inappropriate antibiotics usage. Mangione-Smith et al. (2005) confirm a high inappropriate use of $60-80 \%$ antibiotics in children and adolescents with bronchitis.

In pneumonia cases, the antibiotics used were ampicillin, amoxicillin, ampicillin-sulbactam, cefixime, and ceftriaxone. Pneumonia is an acute infection and inflammation of pulmonary parenchyma that are sometimes followed by inflammation in the bronchi (bronchopneumonia) due to the aspiration of secretions from 
Vol. 15 No. 02 Desember 2018

tracheal colonization (Mackenzie 2016; Reynolds et al., 2010). The most common pathogens causing pneumonia are respiratory viruses or Streptococcus pneumoniae. Viral pneumonia is more common than bacterial pneumonia. The data from the Etiology of Pneumonia in the Community (EPIC) study conducted by the Centers for Disease Control and Prevention $(C D C)$ show that among the 2.222 children with pneumonia, $66 \%$ of the cases are confirmed as viral pneumonia, while bacterial pneumonia is only detected in a few cases (8\%) (Jain et al., 2015). Nevertheless, empirical antibiotics are strongly recommended for suspected pneumonia in both inpatient and outpatient settings (Bradley et al., 2011).

The national guideline list macrolides as the recommended antibiotics for pneumonia, while the international guideline suggests ampicillin or penicillin $G$ as the first line and cefotaxime, ceftriaxone, or levofloxacin as the alternatives (as mentioned in Table 5). On the other hand, most of the cases in this study used a two drug combination, namely the combination of ampicillin and amoxicillin (8 of 13 cases) and the combination of ampicillin-sulbactam and cefixime (1 out of 13 cases). The benefits of taking two antibiotics with a similar spectrum like ampicillin and amoxicillin may outweigh the risks associated with therapeutic duplication. Therefore, only 4 cases were considered compliant with the drug of choice listed in the guidelines. Unfortunately, the duration of the antibiotics use was inappropriate, i.e., less than ten (10) days. Although a shorter course may be as effective as an intensive one, comparative studies with an intensive investigation of short-course therapy for pneumonia have not been performed in the developed world (Bradley et al., 2011).

Various antibiotics were used in the pharyngitis management in this study. Pharyngitis is an inflammation of the pharynx that commonly occurs with inflammation of the tonsils and surrounding tissues (The Indonesian Ministry of Health, 2005). Most of the pharyngitis cases are caused by a viral infection, but up to $30 \%$ of cases in children are caused by bacteria. The most common bacteria causing pharyngitis in children is from the group of a beta-hemolytic Streptococcus (Weber, 2014). The drugs of choice for pharyngitis are penicillin $\mathrm{V}$, clindamycin, 
erythromycin, or first or secondgeneration cephalosporin. On the other hand, antibiotics used in this study were a single or a combination of thirdgeneration of cephalosporins and also ampicillin that was used alone or in combination with first- or thirdgeneration cephalosporins or with amoxicillin (Table 5). Hence, referring to the guidelines, the choice of antibiotics in all cases in this study was identified as inappropriate. Compared with the first-line therapies, ampicillin might be equally effective, and cephalosporins could be used as alternatives to treat inpatients with allergies to penicillin (Regoli et al., 2011). However, the use of ampicillin and cephalosporin must consider cost and effectiveness.

Overall, the major findings of this study reflected high levels of inappropriate antibiotics use in the treatment of pediatric RTIs in the hospital. There were 83 cases (95.40\%) of improper choice of antibiotics and 4 cases $(4.60 \%)$ of the inapproppriate duration of antibiotic therapy among the 109 antibiotics prescriptions over the 87 patients evaluated in this study. The results of this research are higher than the other studies. Evaluating the antibiotics usage in the treatment of upper respiratory tract infection in Ethiopia, Mamo and Teshome (2007) identify that only $60.30 \%$ of prescriptions are adherent to the prescribing guidelines. A similar report by Antoro et al. (2015) says that $46.37 \%$ choices of antibiotics in pediatric upper respiratory tract infection are improper. This report reveals a high rate of noncompliance to guidelines-based prescriptions in the antibiotic treatment of respiratory infections. The discrepancies between the clinical practices and the guidelines may be related to the availability of the first-line drugs, the sensitivity patterns of hospital pathogens (antibiogram), or patients' self responses to the antibiotics, all of which cannot be assessed in this study due to the lack of information. Nevertheless, antibiotics therapy should be based on accurate diagnostics and the evidence-based guidelines, as well as the local antibiogram, to counter the resistance and achieve the optimal outcomes of therapy.

\section{Conclusions}

The results indicated a high level of inappropriate use of antibiotics in the management of pediatric RTIs at 
a primary hospital in Surabaya.

Prescribing antibiotics by considering the local antibiograms, along with the international and local conformable guidelines of antibiotics use, may help to reduce the incidence of inappropriateness.

\section{Acknowledgments}

The author would like to thank the physicians and personnel of the hospital observed in this, as well as Rini Dwi Handayani for her assistance in data collection. The author would also like to express her gratitude to the Pharmacy Acedemy of Surabaya.

\section{References}

Alberta Medical Association. 2008a. Guideline for the Diagnosis and Management of Acute Bronchitis. Edmonton: Alberta Medical Association.

Alberta Medical Association, 2008b. Guideline for the Diagnosis and Management of Acute Pharyngitis. Edmonton: Alberta Medical Association.

Alumran, A., Hurst, C., Hou, X. 2011. Antibiotics overuse in children with upper respiratory tract infections in Saudi Arabia: risk factors and potential interventions. Clinical Medicine and Diagnostics, 1(1):8-16.
Antoro, T. 2015. Evaluasi penggunaan antibiotik pada pasien anak terdiagnosa infeksi saluran pernapasan atas akut (ISPaA) di Puskesmas Kecamatan Kunduran Kabupaten Blora Tahun 2013. Bachelor Thesis. Universitas Muhammadiyah Surakarta.

Arroll, B., Kenealy, T. 2005. Antibiotics for the Common Cold and Acute Purulent Rhinitis. $4^{\text {th }}$ edition. Chichester: The Cochrane Library, John Wiley \& Sons Ltd.

Baktygul, K., Marat, B., Ashirali, Z., Harun-Or-Rashid, M.D., Sakamoto, J. 2011. An assessment of antibiotics prescribed at the secondary health-care level in the Kyrgyz Republic. Nagoya Journal of Medical Science, 73(3-4):157168.

Blomberg, B. 2008. Antimicrobial resistance in developing countries. Tidsskr Nor Laegeforen, 128(21):2462-2466.

Bradley, J.S., Byington, C.L., Shah, S.S., Alverson, B., Carter, E.R., Harrison, C., Kaplan, S.L., Mace, S.E., McCracken, G.H. Jr., Moore, M.R., St. Peter, S.D., Stockwell, J.A., Swanson, J.T. 2011. The management of community-acquired

pneumonia in infants and children older than 3 months of age: clinical practice guidelines by the pediatric infectious diseases society and the infectious diseases society of America. Clinical Infectious Diseases, 53(7):e25-e76. 
Byarugaba, D.K. 2004. A view on antimicrobial resistance in developing countries and responsible risk factors. International Journal of Antimicrobial Agents, 24(2):105110.

Gonzales, R., Steiner, J.F., Sande, M.A. 1997. Antibiotics prescribing for adults with colds, upper respiratory tract infections, and bronchitis by ambulatory care physicians. JAMA, 278(11):901904.

Grigoryan, L., Zoorob, R., Jesal, S., Haijun, W., Monisha, A., Barbara, W.T. 2017. Antibiotic prescribing for uncomplicated acute bronchitis is highest in younger adults. Antibiotics, 6(4):22.

Jain, S., Williams, D.J., Arnold, S.R., Ampofo, K., Bramley, A.M., Reed, C., Stockmann, C., Anderson, E.J., Grijalva, C.G., Self, W.H., Zhu, Y., Patel, A. 2015. Community-Acquired Pneumonia Requiring Hospitalization among U.S. Children. The New England Journal of Medicine, 372:835845.

Karevold, G., Kvestad, E., Nafstad, P., Kvaerner, K.J. 2006. Respiratory infections in schoolchildren: comorbidity and risk factors. Archives of Disease in Childhood, 91(5):391-395.

Mackenzie, G. 2016. The definition and classification of pneumonia. Pneumonia, 8:14.
Mamo, G., Teshome, A. 2017. Evaluation of antibiotics use in the treatment of upper respiratory tract infection in Bedale District Hospital, Southwest Ethiopia. Journal of Scientific and Innovative Research, 6(1):38-43.

Mangione-Smith, R., Wong, L., Elliott, M.N., Mc Donald, L, Roski, J., 2005. Measuring the quality of antibiotic prescribing for upper respiratory infections and bronchitis in 5 US health plans. Archives of Pediatrics and Adolescent Medicine, 159(8):751-757.

The Indonesian Ministry of Health, 2005. Pharmaceutical Care untuk Infeksi Saluran Pernapasan. Jakarta: The Directory of Pharmacy and Medical Devices.

The Indonesian Ministry of Health. 2013. Riset Kesehatan Dasar. Jakarta: Department of Health Research and Development.

Mukherjee, T.K. 2009. Bronchitis: Causes and Treatments, in Handbook of Pulmonary Diseases. New York: Nova Science Publishers, Inc.

Reese, R.E., Betts, R.F., Gumustop, B. 2000. Handbook of Antibiotics. $3^{\text {rd }}$ editions. Philadelphia: Lippincott Williams\&Wilkins.

Regoli, M., Chiappini, E., Bonsignori, F., Galli, L., de Martino, M. 2011. Update on the management of acute pharyngitis in children. 
Italian Journal of Pediatrics, 37:

10.

Reynolds, J.H., McDonald, G., Alton, H., Gordon, S.B. 2010. Pneumonia in the immunocompetent patient. The British Journal of Radiology, 83(996):998-1009.

Wenzel, R.P. and Fowler, A.A. 2006. Acute Bronchitis, In pp. 212530. The New England Journal of Medicine, 355:2125-2130.

Weber, R. 2014. Pharyngitis. Primary Care: Clinics in Office Practice, 41(1):91-98. 